\title{
Classical and neoclassical approaches of management: An overview
}

\author{
${ }^{1}$ Md. Sadrul Islam Sarker, ${ }^{2}$ Mohammad Rafiul Azam Khan \\ ${ }^{1}$ Lecturer, Department of Management Studies, Begum Rokeya University, Rangpur-5400, Bangladesh. \\ ${ }^{2}$ Assistant Professor, Department of Management Studies, Begum Rokeya University, Rangpur-5400, \\ Bangladesh.
}

\begin{abstract}
In this study, the historical development process of classical and neoclassical approach of management has been analyzed. While studying the historical development of management, two basic phases have been identified. These phases are; Taylor, Fayol and Weber composing Classic Term; Hawthorne experiments, human relation movements, and behavioral movements composing Neo-classic Term. This study examines the greatest impact of the classical and neo-classical school to the organization on today's management. Firstly, the paper delineates the important theories propounded by classical and neoclassical theorists. Secondly, the article evaluates the impact of these theories on management thought. Finally, the essay compares its role on managerial thought.
\end{abstract}

Keywords: classical approach, neoclassical approach, management.

\section{Introduction}

Classical approach to management is a set of homogeneous ideas on the management of organizations that evolved in the late $19^{\text {th }}$ century and early $20^{\text {th }}$ century. This perspective emerges from the industrial revolution and centers on theories of efficiency. As at the end of the 19th century, when factory production became pervasive and large scale organizations raised, people have been looking for ways to motivate employees and improve productivity. A need for management ideas came to pass which directed to classical contributors such as Frederick Taylor Henri Fayol and Max generating management theories such as Taylor' Scientific Management, Fayol's Administrative Management and Weber's Bureaucratic management(George,1948). As a reaction to approaches of classical theory which over-emphasized the mechanical and physiological characters of management, came up the schools of neoclassical theory with a more human-oriented approach and emphasis on time needs, drives, behaviors and attitudes of individuals (Singh,1983). Two important groups, namely, human relations school and behavioral schools emerged during 1920 s and 1930s under the neoclassical theory. As in the late 1920's and early 1930's the Hawthorne experiments were conducted by Elton Mayo and his associate leaded to the Behavioral viewpoint. This brought about a Human Relations Movement which included Douglas McGregor's Theory X and Theory Y approach.

The objectives of the study are as follows:

\section{Objectives of the Study}

1. To examine the role of classical and neoclassical approach of management to the development of management thought.

2. To appraise the contribution of classical and neoclassical theorists of management.

3. To compare and contrast between classical and neoclassical theory of management.

4. To outline the problems and conflicting aspects of classical and neoclassical theory.

\section{Methodology}

The paper is descriptive and qualitative in nature as the study is mainly based on secondary data and information. For better understanding the role of classical and neoclassical approach to management related books, articles and paper essay have been viewed. The historical contribution of classical and neoclassical theorists in the field of management has been identified by overviewing their original work.

\section{Literature Review}

This section examines the various studies that are dealt with respect to the contribution of classical and neoclassical approach to management. Management theories in the early period were not really theories, but some discrete practices or experiences. Classical approach of management is the first studies of management, which emphasized rationality and making organizations and workers as efficient as possible. It offers a convenient framework for the education and training of future managers. (S. C. Certo \& S. T. Certo, 2006) Neoclassical approach is the extended form of classical approach of management. It builds on Classical approach, 
but broadens and expands it; it does not totally divorce itself from its predecessor. Rather, neoclassical theory adds a more human element to the science of organization and management. (Gupta C B, 1992). Up until about the late 1950s academic writing about organizational structure was dominated by the classical management school. This held that there was a single organizational structure that was effective in all organizations (Miles R, 1975). According to Batrol (2001), the classical school is characterized by highly structured, with emphasis on the formal organization with clearly defined functions and detailed rules, autocratic leadership, (Bartol et al, 2001). The three greatest proponents of classical theory were Taylor, Fayol, and Weber. Each identifies detailed principles and methods through which this kind of organization could be achieved. Neoclassical theorists recognized the importance of individual or group behavior and emphasized human relations. Based on the Hawthorne experiments, the neoclassical approach emphasized social or human relationships among the operators, researchers and supervisors (Hersey, P \& Blanchard K, 1977). Management theories can be classified into three broad groups. i) Classical management theory ii) Neoclassical management theory iii) Modern management theory .Under each group a few schools of thought are identified. These three groups of schools of management thought, are currently in vogue and found adequate for the purpose (Hitt and others, 1979)

\section{Classical approach of management:}

\section{Analysis and Discussion}

The classical approach to management (1900-1930) was the product of the first concentrated effort to develop a body of management thought. In fact, the management writers who participated in this effort are considered the pioneers of management study. The classical approach recommends that managers continually strive to increase organizational efficiency in order to increase production- the classical approach is based on the following tenets (Certo S C \& Certo S T, 2006). The classical approach to management can be divided into mainly three distinct areas. These are:

a) Lower level management analysis or scientific management

b) Comprehensive analysis of management or administrative management

c) Bureaucratic management

\section{Scientific management theory:}

Scientific management concentrates on the "one best way to perform a task; that is, it investigates how a task situation can be structured to get the highest production from workers. The process of finding this "one best way" has become known as scientific management (Certo S C \& Certo S T, 2006). Although the techniques of scientific management could conceivably be applied to management at all levels, the research, research applications and illustrations relate mostly to lower-level managers. Therefore theory is also referred to lower level management analysis. Scientific management consists primarily of the work of Frederick W. Taylor, Frank and Lilian Gilbreth, and Henry L. Gantt.

Frederick W Taylor (1856-1915) is commonly called the father of scientific management because of the significance of his contribution. He started his career as an apprentice in a small shop in Philadelphia (USA) in 1875.Taylor witnessed much inefficiency (Robbins et al, 2003). He sought to create a mental revolution among both workers and managers by defining clear guidelines for improving production efficiency. He argued that the four principles of management would result in prosperity for both workers and managers. The principles (Robbins et al, 2003) are

1. Develop a science for each element of an individual's work to replace the old rule of thumb method.

2. Scientifically select and then train, teach, and develop the worker.

3. Heartily cooperate with the workers so as to ensure that all work is done in accordance with the principles of the science that has been developed.

4. Divide work and responsibility almost equality between management and workers. Management does all work for which it better suited than the workers.

Frank Gilbreth (1868-1924) and Lilian Gilbreth (1878-1972) were also significant contributors to the scientific method. As a point of interest, the Gilbreths focused on handicapped as well as normal workers. Like other contributors to the scientific method, they subscribed to the idea of finding and using the best way to perform a job. The primary investigative tools in the Gilbreths research were motion study, which consist of reducing each job to the most basic movements possible. Motion analysis is used today primarily to establish job performance standards.

Henry L. Gantt (1861-1919) too, was interested in increasing worker efficiency. Gantt attributed unsatisfactory or ineffective tasks and piece rates (incentive pay for each product piece an individual produces) 
primarily to the fact that these tasks rate were set according to what had been done by workers in the past or on somebody's opinion of what workers could do.

\section{Administrative management:}

Whereas scientific managers emphasize job design approaching the study of management, managers who embrace the comprehensive view - the second area of classical approach are concerned with the entire range of managerial performance. Administrative management focuses on organizational efficiency. This approach is also called comprehensive analysis of management. Among the well-known contributors to the comprehensive view are Henri Fayol, Chester I Barnard, Alvin Brown, Henry Dennision, Luther Gulick and Lyndall Urwick, J Mooney and A C Reily, and Oliver Sheldon (Heames, et al, 2010). The most notable contributor, however, was Henri Fayol (1841-1925). His book General and Industrial management presents a management philosophy that still guides many modern managers. Because of his writings on elements and general principles of management, Henri Fayol is usually regarded as the pioneer of administrative theory (Certo S C \& Certo S T, 2006). The elements of management have outlined - planning, organizing, commanding, coordinating and controlling are still considered worthwhile divisions under which to study, analyze and affect the management process. The general principles of management suggested by Fayol are still considered useful in contemporary management practices. Here are the principles in order developed by Fayol division of work, authority, discipline, unity of command , unity of direction, subordination of individual interest to general interests, remuneration, centralization, scalar chain, order, equity, stability of tenure of personnel, initiative, and esprit de corps.

\section{Bureaucratic Management:}

Bureaucratic management is a stream of classical theory of management. It is "a formal system of organization that is based on clearly defined hierarchical levels and roles in order to maintain efficiency and effectiveness" (Hodgetts et al, 1981). This theory was developed by Max Weber and is widely used in the management of both public and private sector organizations. According to the bureaucratic management approach, organizations are usually divided into hierarchies. These divisions help in creating "strong lines of authority and control (Singh R N, 1983) within the organization. Max Weber (1864-1924) was the first of management theorists who developed a theory of authority structures and relations based on an ideal type of organization he called a bureaucracy - a form of organization characterized by division of labor, a clearly defined hierarchy, detailed rules and regulations, and impersonal relationships (Wren D A, 1994). Bureaucratic management depends upon administration devices. Max Weber presents the ideal organization structure. According to Weber the bureaucratic management approach is based on four principles -Hierarchical positions, rules of system, division of labor for specialization, and impersonal relationship.

\section{Appraisal of classical approach:}

Classical approach made a significant contribution to the development of management theories. This perspective had three primary thrusts (Griffin R.W. 2006). Scientific management focused on employees within organizations and on ways to improve their productivity. Administrative theory focused on the total organization and on way to make it more efficient. Bureaucratic management focused on eliminating managerial inconsistencies that means it emphasized the position rather than person and organization continues even when individual leave. Classical approach highlighted the universal character of management principles (Berdayes $\mathrm{V}$, 2002). It made a clear distinction between operative activities and managerial activities. It also identified the application of scientific method to the problems of management and highlighted the need for mutual cooperation between employers and employees.

Classical approach has been criticized on several counts. First, this theory is said to be too formal, secondly, it is more appropriate for stable and simple organization than for today's dynamic and complex organizations. Thirdly, it often prescribed the universal procedures that are not appropriate in some setting.

\section{Neoclassical approach of management (1930-1960):}

The Neoclassical approach began with the Hawthorne studies in the 1920s (Wikipedia, 2013). It grew out of the limitations of the classical theory. Under classical approach, attention was focused on jobs and machines. After some time workers resisted this approach as it did not provide the social and psychological satisfaction. Therefore, attention shifted towards the human side of management. George Elton Mayo (18901949) is considered to be the founder to the neoclassical theory (Gupta C B, 1992). He was the leader of the team which conducted the famous Hawthorne Experiments at the Western Electric Company (USA) during 1927-1932.

There are mainly three elements of neoclassical theory of management. They are Hawthorne Experiment, Human Relation Movement, and Organizational Behavior. 


\section{Hawthorne experiments:}

The Hawthorne studies were a series of experiments conducted at the Western Electric Company (USA) between 1927 and 1932 that provided new insights into individual and group behavior (Griffin R W, 2006). The research, originally sponsored by General Electric, was conducted by Elton Mayo and his associates. The studies focused on behavior in the workplace. In one experiment involving this group of workers, for example, researchers monitored how productivity changed as a result of changes in working conditions. The Hawthorne studies and subsequent experiments lead scientists to the conclusion that the human element is very important in the workplace. The Hawthorne experiments may classified into four stages: Illumination experiments, Relay assembly test room experiments, Mass interviewing programme, Bank wiring observation room study.

\section{Human relation movement:}

Taking a clue from the Hawthorne Experiments several theorists conducted research in the field of interpersonal and social relations among the members of the organization. These relations are known as human relations. A series of studies by Abraham H. Maslow, Douglas Mc Gregor, Frederick Herzberg, Keth Davis, Rensis Likert and others lead to what is human relation movement (Singh, 1983). Human relation movement argued that workers respond primarily to the social context of the workplace, including social conditioning, group norms and interpersonal dynamics.

\section{Organizational behavior:}

Several psychologists and sociologists began the study of group dynamics, Chris Argyris, Homans Kurt Lewin, R.L. Katz, kahn and others developed the field of organizational behavior. It involves the study of attitudes, behavior and performance of individuals and groups in organizational settings. This approach came to be known as behavioral approach. It is extended and improved version of human relations movement. It is multidimensional and interdisciplinary the application of knowledge drawn from behavioral sciences (Psychology, sociology, anthropology, etc) to the management problems (Cole G A, 1984). Therefore, it is also called behavioral science approach.

\section{Appraisal of neoclassical approach:}

Neoclassical theory has made significant contribution to an understanding of human behavior at work and in organization. It has generated awareness of the overwhelming role of human factor in industry. This approach has given new ideas and techniques for better understanding of human behavior. Contributors to this approach recognize an organization as a social system subject to the sentiments and cultural patterns of the member of the organization, group dynamics, leadership, motivation, participation, job environmental, etc constitute the core of the neoclassical theory. This approach changed the view that employees are tools and furthered the belief that employees are valuable resources. It also laid the foundation for later development in management theory.

Neoclassical approach is not free from limitations. First, it lacks the precision of classical theory because human behavior is unpredictable. Secondly, its conclusions lack scientific validity and suffer from a clinical bias, its findings are tentative. Lastly its application in practice is very difficult because it requires fundamental changes in the thinking and attitude of both management and workers.

\section{Classical Vs Neoclassical theory:}

Classical and neoclassical approach to management made outstanding contribution to the development of management thought. Under classical approach, attention was focused on job and machine. On the other hand, neoclassical approach to management emphasizes on increasing production through an understanding of people. According to proponents of this theory, if managers understand their people and adapt their organizations to them, Organization success will usually follow. However, the classical theory stresses on task and structure while the neoclassical theory emphasizes people aspect.

\begin{tabular}{|l|l|l|}
\hline Points of distinction & Classical approach & Neoclassical approach \\
\hline Focus & functions and economic demand of workers & Emotion and human qualities of workers \\
\hline Structure & Impersonal and mechanistic & Social system \\
\hline Application & Autocratic management and strict rules & Democratic process \\
\hline Emphasize & Discipline and rationality & Personal security and social demand \\
\hline Work goal of worker & Maximum remuneration and reward & Attainment of organizational goal \\
\hline Concept about men & Economic being & Social being \\
\hline Content & $\begin{array}{l}\text { Scientific management, administrative } \\
\text { management, and bureaucratic management }\end{array}$ & $\begin{array}{l}\text { Hawthorne experiment , human relation movement } \\
\text { and organizational behavior }\end{array}$ \\
\hline Relation & Formal & Informal \\
\hline Nature & Mechanistic & Organistic \\
\hline
\end{tabular}




\section{Conclusion}

Classical and neoclassical approaches made a crucial role in the advancement of management theories and practices. The adopted management approaches are important due to the facts that determine the efficiency and congenial environment with which managerial activities are performed. In this era of rapid economic development and industrial expansion of different nations, classical and neoclassical theorists made an undeniable role by developing different techniques of production and it enabled every nation to be involved in this global market. Though classical theory is now treated to be outdated, it is important because it introduced the concept of management as a subject for intellectual analysis and provided a basis of ideas that have been developed by subsequent schools of management thought. Neoclassical approach put overemphasis on human variables and symbolic rewards which may not be appreciated by the recipient's 'significant others'. It serves as the 'backbone' to many current management theories. So, it is clear that the field of management have some remarkable and pertinent theories which are underpinned by pragmatic study evidence. This development holds a rather brighter future for the study, research, and practice of management.

\section{References:}

[1] Geroge Jr, C.S., The History of Management Thougt, New Delhi, N.J.: Prentice Hall Inc. 1948.

[2] Sing,R.N. Management thought and thinkers, New Delhi, Sultan Chand \& Sons, 1983.

[3] Certo S,C \& Certo S,T,Modern Management, $10^{\text {th }}$ ed., New Delhi, Prentice Hall Inc. 2006.

[4] Gupta C,B, Business Organization And Management, $1^{\text {st }}$ ed., New Delhi, Sultan Chand \& Sons, 1992.

[5] Wren, D.A. The Evolution of Management Thought, 4th ed., New York, Wiley, 1994.

[6] Hersey, P. \& Blanchard, K. Management of Organizational Behavior. 3rd ed. Englewood Cliffs, NJ: Prentice-Hall., 1977.

[7] Bartol, K., Martin, D., Tein, M. and Matthews, G. Management: A Pacific Rim Focus, 3rd ed., McGraw-Hill, Roseville, CA. 2001.

[8] Hitt, Michael A, Middlemist, R Dennis and Mathis, Robert L. Effective Management: New York: West Publishing Company, 1979.

[9] Miles, R. Theories of Management: Implications for Organisational Behaviour and Development. New York, McGraw-Hill, 1975.

[10] Geroge Jr, C.S., The History of Management Thought. Englewood Cliffs, N.J.: Prentice Hall Inc. 1972.

[11] Shafritz, J.M., \& Ott, J. S., Classics of Organization History. Philadelphia: Harcourt Brace Publishers. 2001.

[12] Heames, J.T. \& Breland, J.W., Management Pioneer Contributors: 30-Year Review.Journal of Management History, 16(4): 427436. 2010

[13] http:// en.wikipedia.org/wiki/Organizational_theory\#Neoclassical_perspective, 2013.

[14] Griffin, R.W, Management, $8^{\text {th }}$ ed. Newyork, Houghton Mifflin Company, 2006

[15] Berdayes, V. - Traditional management theory as panoptic discourse: language and the constitution of somatic flowsl, Culture and Organization, Vol. 8 No. 1, pp. 35-49. 2002.

[16] Robins S. P., Coulter M. and Vohra N. Management, $10^{\text {th }}$ ed. India, Prentice Hall (Pearson), 2010

[17] Cole, G.A. (1984), Management: Theory and Practice, Guernsey Press, Saints Bay

[18] Wren, D.A. \& Hay, R.D. Management Historians and Business Historians: Differingperceptions of pioneer contributions. The Academy of Management Journal, 20(3): 470-476, 1977.

[19] Robbins, S.P., Bergman, R., Stagg, I. and Coulter, M. Foundations of Management, 2nd ed., Sydney, Prentice-Hall, 2006.

[20] Hitt, Michael A, Middlemist, R Dennis and Mathis, Robert L. Effective Management: New York: West Publishing Company, 1979.

[21] Wren, D.A. The Evolution of Management Thought, 4th ed., New York, Wiley, 1994.

[22] Hodgetts, Richard M and Altman, Steven, History of Management Thought, Paul ed. New York, Mac Millan Publishing, 1981.

[23] Tripathi, P C and Reddy, P N. Principles of Management 2nd ed. New Delhi: Tata MacGraw Hill. 1991.

[24] McFardland, Dalton L, Management: Principles and Practices. 4th ed. New York, Mac Millan Publishing, 1974. 